\title{
Agricultural Service Responsiveness in Nepal
}

Christopher Root

January 2014 


\section{About the Author}

Christopher Root, MA, was an economic development specialist in the International Development Group at RTI International when this research was completed. He is currently a PhD candidate at Michigan State University.
RTI Press publication RR-0020-1401

This PDF document was made available from www.rti.org as a public service of RTI International. More information about RTI Press can be found at http://www.rti.org/rtipress.

RTI International is an independent, nonprofit research organization dedicated to improving the human condition by turning knowledge into practice. The RTI Press mission is to disseminate information about RTI research, analytic tools, and technical expertise to a national and international audience. RTI Press publications are peer-reviewed by at least two independent substantive experts and one or more Press editors.

\section{Suggested Citation}

Root, C. (2014). Agricultural service responsiveness in Nepal (RTI Press publication No. RR-0020-1401). Research Triangle Park, NC: RTI Press. Retrieved from http://www.rti.org/rtipress
This publication is part of the

RTI Research Report series.

RTI International

3040 East Cornwallis Road

PO Box 12194

Research Triangle Park, NC

27709-2194 USA

Tel: $\quad+1.919 .541 .6000$

Fax: $\quad+1.919 .541 .5985$

E-mail:_rtipress@rti.org

Web site: www.rti.org
C2014 Research Triangle Institute. RTI International is a trade name of Research Triangle Institute.

All rights reserved. This report is protected by copyright. Credit must be provided to the author and source of the document when the content is quoted. Neither the document nor partial or entire reproductions may be sold without prior written permission from the publisher.

doi: 10.3768/rtipress.2014.RR.0020.1401

www.rti.org/rtipress 


\title{
Agricultural Service Responsiveness in Nepal
}

\author{
Christopher Root
}

\section{Contents \\ Introduction \\ 2 \\ Background 2 \\ Responsiveness 3 \\ Nepal 4 \\ Methods 6 \\ Identifying Services 6 \\ Survey Design 6 \\ Study Population and Sample 7 \\ Analysis 7 \\ Results \\ Sample Characteristics 7 \\ Priorities

10 \\ Responsiveness \\ Farmer Characteristics Associated With Total Responsiveness \\ Discussion \\ Conclusion \\ References

Acknowledgments Inside back cover services. We found that agricultural service responsiveness across all services included in the study was 59 percent. We also found evidence of inequitable service responsiveness: regression shows that farmer membership in lower socioeconomic groups is associated with lower responsiveness of between 11 and 18 percentage points. Local government responsiveness can be improved by better understanding the differences between the priorities of different socioeconomic groups and by partnering with nongovernmental organizations that have mandates and resources to reach excluded socioeconomic groups. 


\section{Introduction}

The intent of our research was to measure the responsiveness of local government in delivering agricultural services to farmers. It was motivated by the convergence of several factors. One was the food price crises in 2008 and 2011, which increased undernourishment and prevented an estimated 150 million people from escaping poverty (World Bank, 2012). These crises led to the re-prioritization of agriculture among host country governments, donors, and the research community. Another factor was the disintegration of the so-called Washington consensus amid increasing realization of the important role that governments around the world can play in overcoming the market failures that stunt economic development (Wiggins \& Cabral, 2007). These developments have taken place against the backdrop of a world in which most countries have by now implemented some forms of democratization, decentralization, and other participatory governance practices in large measure to increase government responsiveness to citizens (Oxhorn, Tulchin, \& Selee, 2004).

Although the role for local government in agriculture is increasing, there is little research on how well local governments are fulfilling it. Indeed, little is known about how well efforts to increase government responsiveness to citizens across all sectors have fared. Part of the reason for this is that researchers have used different definitions of responsiveness and different, often indirect, methodologies for measuring it. This poses a challenge to researchers, governments, and donors looking to compare the effectiveness of countries' efforts to increase governance effectiveness.

We attempt to fill some of this knowledge void by testing and reporting on local government responsiveness in Nepal using a direct definition and methodology to measure responsiveness, defined here as the local government, within its legal mandate, providing agricultural services to farmers matching those farmers' service priorities. Responsiveness is measured simply as the percentage of farmers receiving the services they rank as top priorities. We also measure the equitability of responsiveness-that is, how responsiveness varies by socioeconomic characteristics, including ethnic grouping, gender, farm size, and whether a farmer sells his or her produce (i.e., is a commercial farmer). We look at a range of agricultural services, including productionrelated services such as extension and irrigation, as well as services to improve farmers' access to inputs and their opportunities to market their produce.

The research took place in Nepal, where the majority of citizens depend on agriculture for their livelihoods and where most farms are small and unable to generate sufficient surplus to lift households out of poverty (USAID, 2012). Consequently, agricultural services are critically important to the country's economic development and poverty alleviation goals. Nepal has taken steps to increase service delivery responsiveness. Deconcentrated line agencies, including the District Agriculture Development Offices (DADOs), are required to solicit the input of citizens in planning services and have those plans approved by the local government. Nepal's recent Agricultural Development Strategy (ADS) will emphasize increasing extension coverage and improving rural infrastructure as well as improving the equity of these agricultural services (Ministry of Agricultural Development, Nepal, 2013).

The rest of this paper proceeds as follows. First we provide a brief review of the literature on government responsiveness and issues in measuring responsiveness. This includes a review of poverty, agriculture, and agricultural services in Nepal, including the two districts studied. Following that is a discussion of the primary survey design and analysis methods used. This is followed by the results of the analysis, a discussion of key findings, and our conclusions.

\section{Background}

This section provides a brief review of literature on government responsiveness as well as background on agriculture and local government in Nepal. First we discuss the determinants of responsiveness, particularly the equitability of responsiveness and how other researchers have defined and measured responsiveness. This is followed by an overview of agriculture in Nepal and the socioeconomic situation of smallholder farmers. The section ends with a review of local governance with respect to agriculture 
and the primary agricultural services available to farmers.

\section{Responsiveness}

Over the past several decades, governments and donors around the world have attempted to increase government responsiveness to citizens' needs and preferences. This was attempted through democratization and decentralization as well as other institutional initiatives to increase citizen participation in policy making and implementation. In addition to improving overall responsiveness, these institutional changes are supposed to improve equity of responsiveness by increasing opportunities for previously marginalized groups to participate in their own governance (Swanson \& Samy, 2003; Speer, 2012).

Scholars and policy makers have claimed that decentralization improves responsiveness primarily through electoral competition, that is, politicians responding to citizens' preferences to win future votes. However, recent research has indicated the effectiveness of non-electoral participation, such as protests, lobbying, petitioning, and direct contact with government officials, in increasing government responsiveness (Cleary, 2007). They have also claimed that decentralization increases government responsiveness to citizens through three channels: First, decentralization brings people closer to their government and therefore is said to improve opportunities for citizen participation and to improve government's knowledge of and motivation to act on citizens' priorities (Swanson \& Samy, 2003). Second, local governments are thought to be able to respond better to citizens' priorities because the citizens of a subnational administrative area are likely to have more homogenous needs than the citizens of an entire nation (Faguet, 2004). Finally, scholars have claimed that decentralization improves service timeliness and efficiency by reducing bureaucratic bottlenecks at multiple levels of government involved in centralized service delivery (Seth, 2009).

In addition to democratization and decentralization, participatory governance mechanisms that involve citizens in planning and evaluating government policies and projects are thought to promote government responsiveness (Speer, 2012).
Participation is also thought to make services more pro-poor, although the literature does not consistently support this claim (Speer, 2012).

Increasing government responsiveness remains a challenge, with a mixed record of demonstrated success through all three channels (Rodden \& Wibbles, 2012). Furthermore, service responsiveness is often lowest for the poorest members of society. The World Bank has attributed this to four factors: lower spending on services for the poor; little of this spending reaching the front lines; poorer performance of services delivered to the poor, including the reluctance of staff to serve in remote areas; and lower demand for services from the poor (World Bank, 2004). ${ }^{1}$

More broadly, the responsiveness of local governments is constrained by four factors. The first is that local governments can be more vulnerable to elite and special interest capture, leading to misallocation of their resources in favor of those elites and special interests. The second is a broad array of incentive issues that lead, for example, to local governments' being more accountable to the central government than to their citizens and local staff not having sufficient incentive to provide citizens with high-quality services. The third is that, as argued by social choice theorists, increasing participation may not lead to better responsiveness outcomes because the heterogeneous preferences of a group may not be accurately captured as a "collective will." Fourth, citizens may not know which level of government is responsible for what, how they can participate in their governance, and other technical issues related to local service provision (Rodden \& Wibbles, 2012).

\section{Measuring Responsiveness}

In addition to these constraints to the responsiveness of local government, there is no shared definition of responsiveness and consequentially no consistent way for researchers to measure it (Rodden \& Wibbles, 2012). The implication of this is that results from different responsiveness research studies are not comparable, so little can be said about the

1 The poor often do not have as high demand for services due to poorer quality services, poverty preventing them from accessing the services, and cultural factors. 
relative responsiveness of different governments or institutional arrangements. Likewise, governments and donors do not have a rigorous way to track and compare their progress toward increasing government responsiveness.

Definitions of responsiveness can be divided broadly into three categories. One category looks at politicians' and local government service providers' willingness "to register the preferences of constituents, that is, by paying attention to their requests and complaints" (Bratton, 2010). Bratton distinguishes this from representation, which he considers to be officials passing along citizen demands to where they can be addressed. Other researchers have looked at the responsiveness of public administration officials (Andrews \& Van der Walle, 2012). Both of these studies measure responsiveness through questionnaires that ask service users about their perceptions of the responsiveness of local government service providers.

Another category of research looks at how well provision of services responds to measures of need, as defined by the researcher. This is typically at the local government administrative unit level, not the household or individual level. For example, Besley and Burges (2002) looked at how well the government of India's food distribution and expenditures on calamity relief responded to people's need, as measured by shortages in food crop production and areas that experienced flooding. Faguet (2004) examined decentralization's effect on responsiveness in Bolivia, defining responsiveness by how well sector-wise public expenditures matched municipal needs in each sector. He defined need on a sector basis; for example, for agriculture, he used male malnutrition levels and for education, he used illiteracy levels.

The third category of research on responsiveness examines whether more civil society participation leads to better local governance responsiveness. In Mexico, Andersson and colleagues (2009) looked at how participation affects measures of responsiveness. They measured civil participation through the periodicity of meetings between community-based organizations (CBOs) and government, the presence of a forum for participatory planning, and the presence of mechanisms for implementing joint projects between CBOs and the government. They measured responsiveness using dummy variables to represent the presence of municipal technicians, whether agricultural services were produced in cooperation with $\mathrm{CBO}$, whether the municipality had positively responded to farmer requests, and whether municipal agricultural management had improved in the past 5 years.

\section{Nepal}

Agriculture is a key component of Nepal's economy and the source of livelihood for the majority of citizens. More than one-third of Nepal's gross domestic product is from agriculture, and more than three-quarters of its households are farm households (Asian Development Bank [ADB], Department for International Development [DFID], and International Labour Organization [ILO], 2009). However, wages are particularly low in agriculture; according to the 2010/2011 Nepal Living Standards Survey (NLSS), of the 25 percent of Nepal's population falling below the national poverty line, more than half are farmers. The incidence of poverty among agricultural wage laborers is nearly double that of the rest of the population (Central Bureau of Statistics, Nepal [CBS], 2011).

Low productivity in the agricultural sector is blamed on a number of factors, including small farm sizes (over half of Nepal's farms are less than half a hectare), expensive transportation in the hills, and weak government services. The weakness of government services in agriculture has been attributed to the lack of a political voice among poor farmers and the consequential lack of political support for agriculture (ADB et al., 2009). This is corroborated by the 2010/2011 NLSS, which found that access to markets or agricultural centers is correlated with lower rates of poverty (CBS, 2011).

This paper looks at not only the responsiveness of local government to all farmers but also the equity of that responsiveness by ethnic group, gender, land size, and commercial orientation. As one might expect given their history at the bottom of the caste system, Dalits have a poverty rate nearly double that of the rest of the population, at 43 percent compared with 23 percent. Somewhat unexpectedly, female- 
headed households have a slightly lower incidence of poverty than male-headed households. Poverty in Nepal correlates closely with land size. In rural areas, those having between 0.2 and 1 hectares are nearly 50 percent more likely to fall under the poverty line than are those with between 1 and 2 hectares of land (CBS, 2011). Finally, commercialization in Nepal is quite low; in 2009, only about 15 percent of agricultural output was sold (ADB et al., 2009).

Nepal's Local Self Governance Act (LSGA) of 1999 provided the legal framework for village and district governments to plan and deliver services, including agricultural services. By devolving responsibility to local governments to develop policies and programs, the LSGA aimed to spur equitable development by enabling the participation of all citizens (Government of Nepal, 1999). Currently line agencies, including the Department of Agriculture, are devolved to the district level through their District Agriculture Development Offices (DADOs). These district-level line offices are accountable both to the District Development Committee (DDC), headed by an appointee from the Ministry of Local Development (MLD), and to their central offices. The majority of a DADO's budget comes from central offices but must be approved by the appointed DDC head; however, the DDC and the Village Development Committee (VDC) tend to use their budget, most of which is centrally dispersed, on infrastructure projects such as roads, schools, and sometimes market structures.

Although the LSGA provided for local elections, these elections were cancelled in 2002 because of the Maoist insurgency. Political parties nominated representatives for the Constituent Assembly, which was formed in 2008 to write the country's new constitution. However, political participation by farmers-particularly smallholder farmers-is low, as they are not well organized to advocate for their interests.

In the absence of elections and because farmers have a weak political voice, participatory planning is the primary channel by which farmers can articulate their preferences to local government. Annual planning and priority setting is carried out at multiple levels, from the sub-village level up to the district level, and is designed to incorporate the input of citizens through well-publicized planning workshops. However, we found that only 3 percent of farmers had provided input into planning either at a workshop or through a farmer group or cooperative leader. This low number likely reflects the fact that input is primarily given by leaders of farmer groups and cooperative representatives. These leader farmers and cooperative representatives may not formally request input from their farmers but still convey their farmers' preferences to local government.

We also studied farmers who were affiliated with iDE (formerly International Development Enterprises), an international nongovernmental organization (NGO) that has worked in Nepal for over 20 years. iDE works to improve the incomes of smallholder farmers by improving their access to agricultural inputs, innovations in farming practices, and markets. A key part of iDE's approach is helping farmers organize, and developing marketing and planning committees that manage wholesale markets. iDE helps these committees advocate for and obtain services and support from DADOs on behalf of their member farmers. In addition, iDE collaborates with DADOs, often implementing its programs through DADO staff.

Our study includes seven services provided to the agricultural sector in Nepal by the local government consistent with the guidelines set forth by the LSGA. Farmer group development and support, primarily provided by DADOs, involves forming new farmer groups and providing services that strengthen the group. Being a member of a farmer group and registered with a DADO is a prerequisite to receiving extension services. Extension services include classroom training on production and plant protection; lead farmers or the government conducting demonstrations, often involving the distribution of samples; exposure visits to commercial farms; seed multiplication training; and training in integrated pest management. Because limited resources allow DADO representatives to reach only a fraction of farmers, DADOs also provide training to input sellers. The idea behind this is that these input sellers will pass on embedded technical services to their farmer customers as a value-added service to increase customer loyalty. DADOs are to varying extents involved in maintaining input 
quality and availability through activities such as supporting seed producer groups and seed banks, monitoring seed quality, and at times distributing subsidized seeds. Irrigation includes large- and small-scale surface irrigation, piped irrigation, and micro-irrigation technologies such as drip systems, sprinklers, and diesel and treadle pumps. Irrigation user groups manage irrigation water use and irrigation maintenance. DDCs, VDCs, and DADOs may construct and sometimes facilitate the management of markets where farmers sell their produce, either directly to consumers or through traders. Finally, we studied roads farmers use to get to and from market.

This research took place in two districts, Gulmi and Kapilvastu, both of which are in the Western Development region of Nepal. These were selected for this research for several reasons. First, they are in the Midhill and Terai (plains) areas, respectively, where most Nepalese live. Second, they represented strong and weak local governments, providing an opportunity to test this pilot methodology under different governance conditions. According to the Ministry of Local Development's Minimum Conditions and Performance Measures (MCPM) assessment, Gulmi was the 4th-best-performing district in Nepal in 2010/2011, whereas Kapilvastu ranked 69th out of 75 districts (MLD, 2011). One key difference between the two districts that may explain some of the difference in governance quality is the number of political parties and the level of cooperation between them. The 3 or 4 political parties in Gulmi are viewed to be relatively cooperative, whereas in Kapilvastu the 15 or so parties mainly represent different ethnic groups, and the planning and provision of services and projects is more contested. Gulmi is also better off socioeconomically: 25.6 percent of Gulmi's population is in poverty, compared with 35.5 percent of Kapilvastu's (CBS, 2011).

\section{Methods}

The primary method used for this study was a farmer service user survey with 200 respondents divided evenly between the two study districts. This survey asked farmers which agricultural services were the responsibility of government to provide. We conducted follow-up in-depth interviews with some farmers to add qualitative depth and context.

\section{Identifying Services}

To identify the services provided by local government to farmers in Nepal, we consulted with national and local government officials as well as NGO staff and reviewed policy documents. We considered a service to be the responsibility of local government if the service was delivered by the DDC itself or if there were formalized lines of accountability and coordination between the devolved line agency responsible for delivering the service and the DDC. From an initial list of 11 services suspected to be provided by local government, we eliminated 3 that we found were not the responsibility of local government.

\section{Survey Design}

These identified services formed the basis of the farmer service user questionnaire. For each of the seven services, we designed a questionnaire to assess three dimensions of service effectiveness: utilization, quality, and priority. Utilization is whether a respondent uses a service provided by the local government. Quality, a dimension not investigated in this study, is how well the service fulfills its fundamental purpose according to the survey respondents. We assessed priority by asking farmers to select the five top priority services for them to receive. The question was, "Which of the following services are the highest priorities for you to receive? Please choose exactly five."

This question does not distinguish between services respondents were receiving at the time of the interview and services they wished to receive in the future. By combining into one question priorities about current and future services, we aimed at simplicity and assumed that the priority is the same for continuing to receive an important service or receiving that service for the first time. However, we did not test this assumption, and it could be a source of bias if, for example, farmers are more likely to rate something they have not yet received as a priority over something they have received. 


\section{Study Population and Sample}

To test the methodology under a range of local government contexts, we purposefully chose two districts for this pilot study, one with a strong local government and one with a weak local government, as described in the Background section. The farmer service user survey design used a stratified cluster sample of 200 farmers, 100 from each of the two chosen districts. Within each district, we selected three VDCs-from 100 in Gulmi and 77 in Kapilvastu. The three VDCs from each district represent three categories of VDCs:

- those where DADOs had a strong presence;

- those where research partner iDE was working; and

- those where neither DADOs nor iDE was present.

For each of the three VDC types in each of the two districts, sample VDCs were selected randomly from a list that contained all the VDCs that were within 2 hours from the district capital. This restriction was necessary because of time and resource constraints. Within each VDC in the study, three wards were randomly chosen out of the nine wards that constitute a VDC. Eleven or 12 farmers were chosen from each of the three wards in each VDC. In the DADO and iDE VDCs, these farmers were randomly chosen from a list. In VDCs characterized as affiliated with neither a DADO nor iDE, farmers were selected using a random walk method. Table 1 shows the number of respondents in each of the six VDCs.

\begin{tabular}{|c|c|c|c|c|}
\hline District & District Type & VDC & $\begin{array}{l}\text { Farmer } \\
\text { VDC } \\
\text { Affiliation }\end{array}$ & Respondents \\
\hline \multirow[t]{3}{*}{ Gulmi } & \multirow{3}{*}{$\begin{array}{l}\text { Stronger } \\
\text { local } \\
\text { government }\end{array}$} & Arkahle & DADO & 34 \\
\hline & & Hadineta & iDE & 33 \\
\hline & & Kharjyang & Neither & 33 \\
\hline \multirow[t]{3}{*}{ Kapilvastu } & \multirow{3}{*}{$\begin{array}{l}\text { Weaker } \\
\text { local } \\
\text { government }\end{array}$} & Lalpur & DADO & 34 \\
\hline & & Sauraha & iDE & 33 \\
\hline & & Manpur & Neither & 33 \\
\hline 2 districts & $\begin{array}{l}2 \text { local } \\
\text { government } \\
\text { types }\end{array}$ & $6 \mathrm{VDCs}$ & $\begin{array}{l}3 \mathrm{VDC} \\
\text { types }\end{array}$ & $\begin{array}{l}200 \\
\text { farmers }\end{array}$ \\
\hline
\end{tabular}

DADO = District Agriculture Development Office; VDC = Village Development Committee.

\section{Analysis}

Our analysis of local government responsiveness proceeds in four steps. First we describe the sample by farmer VDC affiliation and by district to understand the distribution of socioeconomic characteristics. This is followed by our analysis of the percentage of farmers who ranked each service as a top-five priority for them to receive. Following this is our analysis of local government responsiveness to those priorities, that is, the percentage of farmers receiving the services they rank as top priorities to receive. Finally, we use ordinary least squares (OLS) regression to analyze which farmer characteristics are associated with overall government responsiveness.

Throughout the analysis, results are disaggregated by seven population characteristics, which are later included as control variables in the regression: farmer affiliation, district, gender, ethnic grouping, land size, commercial orientation, and membership in a cooperative. We used farmer VDC affiliationDADO, iDE, or neither-to examine differences in responsiveness for farmers registered with their DADO, those working with iDE, and those not working with either. The variable district is included to allow for analysis of differences between Hill (Gulmi) and Terai (Kapilvastu) regions of Nepal, and also between districts with strong and weak local governments.

\section{Results}

This section contains results in the form of four tables that describe sample characteristics, priorities, responsiveness rates, and farmer results.

\section{Sample Characteristics}

Table 2 shows the characteristics of the sample. The columns show the entire sample as well as the farmer affiliation and district characteristics used for the sample design, as described in the Study Population and Sample section. The rows show other characteristics of the sample used to determine the equity of local government responsivenessfarmer affiliation and district characteristics used for the sample design, as described in the Study Population and Sample section. The rows show other 
Table 2. Characteristics of the sample, by farmer Village Development Committee affiliation and district

\begin{tabular}{|c|c|c|c|c|c|c|}
\hline \multirow[b]{2}{*}{ Farmer Characteristics } & \multirow[b]{2}{*}{$\begin{array}{l}\text { Entire Sample } \\
\qquad(N=200)\end{array}$} & \multicolumn{3}{|c|}{ Farmer VDC Affiliation } & \multicolumn{2}{|c|}{ District } \\
\hline & & $\begin{array}{c}\text { DADO } \\
(n=68)\end{array}$ & $\begin{array}{c}\text { IDE } \\
(n=66)\end{array}$ & $\begin{array}{l}\text { Neither } \\
(n=66)\end{array}$ & $\begin{array}{c}\text { Gulmi } \\
(n=100)\end{array}$ & $\begin{array}{c}\text { Kapilvastu } \\
(n=100)\end{array}$ \\
\hline \multicolumn{7}{|l|}{ Gender } \\
\hline Male & $81 \%$ & $88 \% *$ & $68 \% *$ & $86 \% *$ & $71 \% *$ & $91 \% *$ \\
\hline Female & $19 \%$ & $12 \% *$ & $32 \% *$ & $14 \% *$ & $29 \% *$ & $9 \% *$ \\
\hline \multicolumn{7}{|l|}{ Ethnic grouping } \\
\hline Dalit & $10 \%$ & $4 \% *$ & $10 \% *$ & $15 \% *$ & $8 \% *$ & $11 \% *$ \\
\hline Janajati & $60 \%$ & $47 \% *$ & $62 \% *$ & $72 \% *$ & $33 \% *$ & $89 \% *$ \\
\hline Other & $30 \%$ & $48 \% *$ & $29 \% *$ & $12 \% *$ & $59 \% *$ & $0 \% *$ \\
\hline \multicolumn{7}{|l|}{ Land size } \\
\hline$<0.25$ hectares & $29 \%$ & $22 \% *$ & $38 \% *$ & $29 \% *$ & $46 \% *$ & $12 \% *$ \\
\hline $0.25-0.5$ hectares & $27 \%$ & $37 \% *$ & $29 \% *$ & $17 \% *$ & $37 \% *$ & $18 \% *$ \\
\hline$>0.5$ hectares & $43 \%$ & $42 \% *$ & $33 \% *$ & $55 \% *$ & $17 \% *$ & $70 \% *$ \\
\hline \multicolumn{7}{|l|}{ Commercial farmer } \\
\hline No & $50 \%$ & $43 \% *$ & $20 \% *$ & $89 \% *$ & $52 \%$ & $49 \%$ \\
\hline Yes & $50 \%$ & $57 \% *$ & $80 \% *$ & $11 \% *$ & $48 \%$ & $51 \%$ \\
\hline \multicolumn{7}{|l|}{ Member of cooperative } \\
\hline No & $70 \%$ & $72 \% *$ & $52 \% *$ & $86 \% *$ & $72 \% *$ & $68 \% *$ \\
\hline Yes & $30 \%$ & $28 \% *$ & $48 \% *$ & $14 \% *$ & $28 \% *$ & $32 \% *$ \\
\hline
\end{tabular}

* Significant group differences $(p<.05)$. DADO = District Agriculture Development Office.

Note: In some cases detail does not sum to 100 because of rounding.

characteristics of the sample used to determine the equity of local government responsiveness.

In the entire sample, the majority (81 percent) of farmer respondents were males. Because of targeting, iDE served the highest percentage of female farmers, at nearly one-third. In the entire sample, 60 percent of respondents were Janajati, or native Nepalis. This ethnic group generally occupies the middle socioeconomic strata between the Dalits (lower class), who represent 10 percent of the sample, and what is labeled here as "Other." This last category encompasses traditionally better-off ethnic groups such as Brahmin and Chhetri and made up 30 percent of the sample.

Table 2 shows that DADOs served the lowest percentage of Dalits and the highest percentage of farmers belonging to the Other ethnic group category by a significant margin. iDE also reached fewer Dalits and more farmers in the Other ethnic group category than were in the VDCs that were served by neither a DADO nor iDE. In Gulmi, the majority of the sample fell under the Other ethnic group category, whereas in Kapilvastu the majority were Janajati.

In the entire sample, more than half of the respondents farmed less than half a hectare of land. iDE reached a slightly higher percentage of farmers with less than half a hectare of land (67 percent) than DADOs did (59 percent). Perhaps surprisingly, 55 percent of the farmers who were affiliated with neither a DADO nor iDE (labeled "Neither") had more than half a hectare of land. Despite containing the most traditionally disadvantaged ethnic groups, these VDCs had the fewest respondents with less than half a hectare of land. One tentative explanation is that these VDCs have lower land values, in part 
because of their remoteness, which makes them more difficult for DADO and NGOs such as iDE to reach.

Half of the farmers in the sample grew commercial crops. Unsurprisingly, given the commercial orientation of iDE's program, 80 percent of iDE farmers grew commercial crops compared with 57 percent of DADO farmers and 11 percent of farmers affiliated with neither iDE nor a DADO. Finally, only 30 percent of the farmers were affiliated with a cooperative or collection center, which indicates increased market and political power. Nearly half of iDE farmers were members of cooperatives or collection centers, compared with 28 percent of DADO farmers and 14 percent of farmers affiliated with neither.

\section{Table 3. Priorities: percentage of farmers ranking services as a priority}

\begin{tabular}{|c|c|c|c|c|c|c|c|}
\hline $\begin{array}{l}\text { Farmer } \\
\text { Characteristics }\end{array}$ & $\begin{array}{l}\text { Farmer Group } \\
\text { Development }\end{array}$ & $\begin{array}{l}\text { Extension } \\
\text { Services }\end{array}$ & $\begin{array}{c}\text { Embedded } \\
\text { Technical Services }\end{array}$ & $\begin{array}{l}\text { Input Quality } \\
\text { and Availability }\end{array}$ & Irrigation & $\begin{array}{l}\text { Market } \\
\text { Structures }\end{array}$ & Roads \\
\hline Overall (n=199) & $37 \%$ & $57 \%$ & $53 \%$ & $90 \%$ & $82 \%$ & $59 \%$ & $41 \%$ \\
\hline \multicolumn{8}{|l|}{ Farmer affiliation } \\
\hline DADO $(n=68)$ & $47 \%$ & $56 \%$ & $54 \%$ & $90 \%$ & $74 \%$ & $54 \%$ & $35 \% *$ \\
\hline $\mathrm{iDE}(n=66)$ & $33 \%$ & $48 \%$ & $56 \%$ & $91 \%$ & $86 \%$ & $71 \%$ & $27 \% *$ \\
\hline Neither $(n=65)$ & $29 \%$ & $68 \%$ & $48 \%$ & $89 \%$ & $86 \%$ & $52 \%$ & $62 \% *$ \\
\hline \multicolumn{8}{|l|}{ District } \\
\hline Gulmi ( $n=99)$ & $57 \% *$ & $32 \% *$ & $69 \% *$ & $84 \% *$ & $66 \% *$ & $41 \% *$ & $29 \% *$ \\
\hline Kapilvastu $(n=100)$ & $17 \% *$ & $82 \% *$ & $37 \% *$ & $96 \% *$ & $98 \% *$ & $77 \% *$ & $53 \% *$ \\
\hline \multicolumn{8}{|l|}{ Gender } \\
\hline Male $(n=159)$ & $33 \%$ & $60 \% *$ & $52 \%$ & $91 \%$ & $86 \% *$ & $62 \%$ & $47 \% *$ \\
\hline Female $(n=38)$ & $50 \%$ & $42 \% *$ & $61 \%$ & $87 \%$ & $68 \% *$ & $47 \%$ & $21 \% *$ \\
\hline \multicolumn{8}{|l|}{ Ethnic grouping } \\
\hline Dalit $(n=19)$ & $32 \% *$ & $79 \% *$ & $32 \% *$ & $89 \%$ & $79 \% *$ & $53 \% *$ & $47 \% *$ \\
\hline Janajati $(n=117)$ & $25 \% *$ & $67 \% *$ & $46 \% *$ & $93 \%$ & $94 \% *$ & $68 \% *$ & $53 \% *$ \\
\hline Other $(n=59)$ & $63 \% *$ & $31 \% *$ & $73 \% *$ & $85 \%$ & $58 \% *$ & $44 \% *$ & $17 \% *$ \\
\hline \multicolumn{8}{|l|}{ Land size } \\
\hline$<0.25 \mathrm{Ha}(n=58)$ & $53 \% *$ & $41 \% *$ & $57 \% *$ & $79 \% *$ & $79 \%$ & $47 \% *$ & $36 \% *$ \\
\hline $0.25-0.5 \mathrm{Ha}(n=53)$ & $40 \% *$ & $49 \% *$ & $68 \% *$ & $92 \% *$ & $74 \%$ & $53 \% *$ & $26 \% *$ \\
\hline$>0.5 \mathrm{Ha}(n=85)$ & $25 \% *$ & $72 \% *$ & $42 \% *$ & $95 \% *$ & $88 \%$ & $71 \% *$ & $52 \% *$ \\
\hline \multicolumn{8}{|l|}{ Commercial farmer } \\
\hline Yes $(n=99)$ & $39 \%$ & $56 \%$ & $56 \%$ & $90 \%$ & $78 \%$ & $64 \%$ & $31 \% *$ \\
\hline No $(n=100)$ & $34 \%$ & $59 \%$ & $50 \%$ & $90 \%$ & $86 \%$ & $55 \%$ & $51 \% *$ \\
\hline \multicolumn{8}{|c|}{ Member of a cooperative } \\
\hline Yes $(n=60)$ & $43 \%$ & $62 \% *$ & $48 \%$ & $90 \%$ & $82 \%$ & $67 \% *$ & $30 \%$ \\
\hline No $(n=76)$ & $41 \%$ & $39 \% *$ & $62 \%$ & $88 \%$ & $71 \%$ & $43 \% *$ & $41 \%$ \\
\hline
\end{tabular}

* Significant group differences $(p<.05)$. DADO = District Agriculture Development Office; Ha = hectare. 


\section{Priorities}

Table 3 shows findings for farmers' service priorities. The columns show priorities for the seven services, and the rows show the priorities overall and disaggregated by farmer characteristic. The remainder of this section highlights overall priorities as well as statistically significant differences in service priorities by farmer characteristic.

\section{Overall Priorities}

The two highest-rated services were input quality and availability (90 percent) and irrigation (82 percent). Other high-priority services were market structures (59 percent), extension services (57 percent), and embedded technical services (53 percent).

\section{Farmer Affiliation}

The only statistically significant differences by farmer affiliation were for roads, which farmers who were affiliated with neither a DADO nor iDE prioritized nearly twice as frequently as DADO and iDE farmers did.

\section{District}

Statistically significant differences emerged in the service priorities of farmers between the two districts. In Kapilvastu, 98 percent of respondents prioritized irrigation compared with 66 percent in Gulmi. Kapilvastu respondents also prioritized extension services far more frequently than Gulmi respondents did ( 82 percent vs. 32 percent). On the other hand, Gulmi respondents prioritized farmer group development (57 percent) and embedded technical services (69 percent) more frequently than Kapilvastu respondents did (17 percent and 37 percent, respectively).

\section{Gender}

Men prioritized extension services, irrigation, and roads more highly than women did. The starkest difference was for roads, which were considered a priority for 47 percent of men compared with only 21 percent of women.

\section{Ethnic Grouping}

Service priorities also varied significantly by ethnic grouping: 79 percent of Dalits and 67 percent of Janajatis prioritized extension services compared with 31 percent of those in the Other ethnic group category. By contrast, 73 percent of farmers in the Other ethnic group category prioritized embedded technical services, compared with 46 percent and 32 percent of Janajatis and Dalits, respectively.

\section{Land Size, Commercial Farmer, and Member of Cooperative}

Larger-scale farmers (those with over half a hectare) prioritized market structures and roads at a higher percentage ( 71 percent and 52 percent) than did smaller farmers. The only significant difference in priorities between commercial and non-commercial farmers was that non-commercial farmers prioritized access to roads at 51 percent compared with 31 percent of commercial farmers. Finally, cooperative members rated extension services (62 percent) and market structures (67 percent) as significantly higher priorities than did those not part of cooperatives (39 percent and 43 percent, respectively).

\section{Responsiveness}

This section examines local governments' responsiveness to farmers' priorities, that is, the percentage of farmers who ranked each service as a priority who also received that service. Table 4 presents this responsiveness and follows the same layout as Table 3, except that the final column shows total responsiveness. Total responsiveness is the weighted average responsiveness across all services. The remainder of this section highlights statistically significant responsiveness differences.

\section{Overall Responsiveness}

The highest rates of government responsiveness were for input quality and availability (81 percent) and market structures (72 percent). The lowest rates were for farmer group development (35 percent) and roads (44 percent). 
Table 4. Responsiveness: percentage of farmers receiving services who ranked those services as a priority (number of eligible farmers ranking that service as a priority in parentheses)

\begin{tabular}{|c|c|c|c|c|c|c|c|c|}
\hline $\begin{array}{l}\text { Farmer } \\
\text { Characteristics }\end{array}$ & $\begin{array}{l}\text { Farmer Group } \\
\text { Development }\end{array}$ & $\begin{array}{l}\text { Extension } \\
\text { Services }\end{array}$ & $\begin{array}{l}\text { Embedded } \\
\text { Technical } \\
\text { Services }\end{array}$ & $\begin{array}{l}\text { Input } \\
\text { Quality and } \\
\text { Availability }\end{array}$ & Irrigation & $\begin{array}{c}\text { Market } \\
\text { Structures }\end{array}$ & Roads & Totala \\
\hline Overall & $35 \%(51)$ & $53 \%(68)$ & $64 \%(103)$ & $81 \%(179)$ & $57 \%(163)$ & $72 \%(118)$ & $44 \%(82)$ & $59 \%$ (199) \\
\hline \multicolumn{9}{|c|}{ Farmer affiliation } \\
\hline DADO & $7 \% *(22)$ & $26 \% *(34)$ & $67 \% *(36)$ & $87 \%(61)$ & $58 \% *(50)$ & $89 \% *(37)$ & $46 \%(24)$ & $54 \% *(68)$ \\
\hline $\mathrm{iDE}$ & $73 \% *(28)$ & $87 \% *(31)$ & $89 \% *(36)$ & $93 \%(60)$ & $89 \% *(57)$ & $59 \% *(47)$ & $50 \%(18)$ & $85 \% *(66)$ \\
\hline Neither & $0 \% *(1)$ & $0 \% *(3)$ & $32 \% *(31)$ & $62 \%(58)$ & $23 \% *(56)$ & $62 \% *(34)$ & $40 \%(40)$ & $37 \% *(65)$ \\
\hline \multicolumn{9}{|l|}{ District } \\
\hline Gulmi & $36 \%(36)$ & $79 \% *(19)$ & $53 \% *(66)$ & $69 \% *(83)$ & $52 \%(65)$ & $71 \%(41)$ & $3 \% *(29)$ & $48 \% *(99)$ \\
\hline Kapilvastu & $33 \%(15)$ & $43 \% *(49)$ & $84 \% *(37)$ & $92 \% *(96)$ & $60 \%(98)$ & $73 \%(77)$ & $66 \% *(53)$ & $69 \% *(100)$ \\
\hline \multicolumn{9}{|l|}{ Gender } \\
\hline Male & $38 \%(37)$ & $51 \%(55)$ & $65 \%(80)$ & $84 \% *(144)$ & $57 \%(136)$ & $69 \%(98)$ & $49 \% *(74)$ & $60 \%$ (159) \\
\hline Female & $31 \%(13)$ & $58 \%(12)$ & $61 \%(23)$ & $67 \% *(33)$ & $54 \%(26)$ & $83 \%(18)$ & $0 \% *(8)$ & $52 \%(38)$ \\
\hline \multicolumn{9}{|l|}{ Ethnic grouping } \\
\hline Dalit & $33 \%(3)$ & $43 \%(7)$ & $50 \%(6)$ & $89 \%$ (19) & $60 \%(15)$ & $60 \%(10)$ & $22 \% *(9)$ & $49 \% *(19)$ \\
\hline Janajati & $35 \%(17)$ & $44 \%(45)$ & $68 \%(53)$ & $93 \%(117)$ & $54 \%(100)$ & $72 \%(79)$ & $52 \% *(62)$ & $60 \% *(117)$ \\
\hline Other & $33 \%(30)$ & $79 \%(14)$ & $60 \%(30)$ & $85 \%(59)$ & $65 \%(34)$ & $73 \%(26)$ & $10 \% *(10)$ & $58 \% *(59)$ \\
\hline \multicolumn{9}{|l|}{ Land size } \\
\hline$<0.25 \mathrm{Ha}$ & $43 \%(21)$ & $67 \%(12)$ & $59 \%(32)$ & $79 \% *(58)$ & $50 \%(46)$ & $67 \%(27)$ & $10 \% *(21)$ & $47 \% *(58)$ \\
\hline $0.25-0.5 \mathrm{Ha}$ & $15 \%(13)$ & $64 \%(22)$ & $61 \%(36)$ & $92 \% *(53)$ & $56 \%(39)$ & $64 \%(28)$ & $36 \% *(14)$ & $57 \% *(53)$ \\
\hline$>0.5 \mathrm{Ha}$ & $41 \%(17)$ & $45 \%(31)$ & $71 \%(35)$ & $95 \% *(85)$ & $63 \%(75)$ & $82 \%(60)$ & $64 \% *(44)$ & $70 \% *(85)$ \\
\hline \multicolumn{9}{|c|}{ Commercial farmer } \\
\hline Yes & $39 \%(38)$ & $62 \% *(47)$ & $79 \% *(53)$ & $97 \% *(89)$ & $82 \% *(77)$ & $94 \% *(63)$ & $68 \% *(31)$ & $78 \% *(99)$ \\
\hline No & $23 \%(13)$ & $33 \% *(21)$ & $48 \% *(50)$ & $66 \% *(90)$ & $35 \% *(86)$ & $47 \% *(55)$ & $29 \% *(51)$ & $40 \% *(100)$ \\
\hline \multicolumn{9}{|c|}{ Member of cooperative } \\
\hline Yes & $48 \%(25)$ & $72 \%(29)$ & $82 \% *(28)$ & $98 \%(54)$ & $73 \% *(49)$ & $70 \%(33)$ & $61 \% *(18)$ & $76 \% *(60)$ \\
\hline No & $31 \%(16)$ & $83 \%(12)$ & $54 \% *(46)$ & $70 \%(67)$ & $48 \% *(54)$ & $85 \%(40)$ & $29 \% *(31)$ & $50 \% *(76)$ \\
\hline
\end{tabular}

* Significant group difference $(p<.05)$. DADO = District Agriculture Development Office; Ha = hectare.

a Total includes irrigation user group development, which was ranked a priority by 12 respondents and received by 1 of those respondents.

Note: The numbers in parentheses represent the eligible farmers and therefore are lower in many cases than the total number of farmers who ranked the service as a priority. For example, only farmers in farmer groups (here, DADO and iDE) are eligible to receive farmer group development or extension services. 


\section{Farmer Affiliation}

Total responsiveness varied significantly by farmer affiliation, with iDE farmers experiencing the highest responsiveness at 85 percent, followed by DADO farmers at 54 percent and then farmers affiliated with neither at 37 percent. These differences in responsiveness are explained in part by extreme differences in farmer group development and extension services. Responsiveness to iDE farmers for farmer group development and extension services was 73 percent and 87 percent, respectively, compared with 7 percent and 26 percent, respectively, for DADO farmers, while farmers in the Neither category experienced zero responsiveness for these services. Embedded technical services responsiveness also differed by farmer affiliation: 89 percent of iDE farmers who prioritized embedded technical services received it, compared with 67 percent of DADO farmers and 32 percent of farmers affiliated with neither. Significant differences in irrigation responsiveness existed as well, with 89 percent responsiveness for iDE farmers, 58 percent for DADO farmers, and 23 percent for farmers affiliated with neither. The high responsiveness for iDE farmers was due to that program's promotion of micro-irrigation. Market structure responsiveness was highest for DADO farmers at 89 percent, compared with 59 percent for iDE farmers and 62 percent for farmers affiliated with neither.

\section{District}

Total responsiveness was higher in Kapilvastu than Gulmi at 69 percent compared with 48 percent. A major difference was in responsiveness with respect to roads: hilly Gulmi experienced only 3 percent responsiveness compared with the plains district Kapilvastu, where responsiveness was 66 percent. Responsiveness in Kapilvastu was also higher for input quality and availability (92 percent compared with 69 percent in Gulmi) and embedded technical services ( 84 percent vs. 53 percent in Gulmi). On the other hand, extension service responsiveness was better in Gulmi at 79 percent compared with 43 percent in Kapilvastu.

\section{Gender}

There was no significant difference in total responsiveness by gender. However, responsiveness for men was significantly higher than for women for roads (49 percent vs. 0 percent) and for input quality and availability (84 percent vs. 67 percent).

\section{Ethnic Grouping}

Total responsiveness was significantly different by ethnic grouping, with responsiveness for Dalits lowest at 49 percent, followed by 58 percent for those in the Other ethnic group category and 60 percent for Janajatis. However, roads were the only service for which responsiveness varied significantly by ethnic grouping: 52 percent for Janajatis, 22 percent for Dalits, and 10 percent for those in the Other ethnic group category.

\section{Land Size, Commercial Farmer, and Member of Cooperative}

Responsiveness varied significantly by land size. Total responsiveness for farmers with less than a quarter of a hectare of land was 47 percent. For those with between a quarter hectare and a half hectare of land, total responsiveness was 57 percent, and for farmers with more than half a hectare of land, total responsiveness was 70 percent. At the individual service level, significant differences by land size existed for roads and quality and availability of inputs, with responsiveness increasing with land size.

Responsiveness was significantly greater for commercial farmers than subsistence farmers. For commercial farmers, overall responsiveness was 78 percent, compared with 40 percent for noncommercial farmers. This difference in responsiveness was constant and statistically significant across all services except farmer group development.

Finally, total responsiveness was significantly higher for those in cooperatives ( 76 percent) compared with those who were not (50 percent). These differences were significant for embedded technical services, irrigation, and roads. 


\section{Farmer Characteristics Associated With Total Responsiveness}

Table 5 shows results from an OLS regression of the farmer characteristics used throughout this analysis on total service responsiveness. This regression analysis allowed us to identify the significance

\begin{tabular}{|c|c|c|c|c|c|}
\hline \multirow{3}{*}{$\begin{array}{l}\text { Farmer } \\
\text { Characteristics } \\
\text { Intercept }\end{array}$} & \multicolumn{3}{|c|}{ Standard } & \multirow{2}{*}{\multicolumn{2}{|c|}{$\begin{array}{l}95 \% \text { Confidence } \\
\text { Interval }\end{array}$}} \\
\hline & \multirow{2}{*}{\begin{tabular}{|c|} 
Coefficient \\
0.67
\end{tabular}} & \multirow{2}{*}{$\begin{array}{l}\text { Error } \\
\mathbf{0 . 0 8}\end{array}$} & \multirow{2}{*}{$\begin{array}{c}\text { P-value } \\
0.00\end{array}$} & & \\
\hline & & & & 0.51 & 0.83 \\
\hline \multicolumn{6}{|c|}{ Farmer affiliation } \\
\hline DADO & 0.19 & 0.07 & 0.01 & 0.05 & 0.32 \\
\hline $\mathrm{iDE}$ & 0.46 & 0.06 & 0.00 & 0.33 & 0.58 \\
\hline Neither & - & - & - & & \\
\hline \multicolumn{6}{|l|}{ District } \\
\hline Gulmi & -0.25 & 0.06 & 0.00 & -0.37 & -0.12 \\
\hline Kapilvastu & - & - & - & - & - \\
\hline \multicolumn{6}{|l|}{ Gender } \\
\hline Male & - & - & - & - & - \\
\hline Female & -0.12 & 0.05 & 0.02 & -0.22 & -0.02 \\
\hline \multicolumn{6}{|c|}{ Ethnic grouping } \\
\hline Dalit & -0.18 & 0.08 & 0.03 & -0.33 & -0.02 \\
\hline Janajati & -0.15 & 0.06 & 0.01 & -0.27 & -0.03 \\
\hline Other & - & - & - & - & - \\
\hline \multicolumn{6}{|l|}{ Land size } \\
\hline$<0.25 \mathrm{Ha}$ & -0.13 & 0.06 & 0.02 & -0.24 & -0.02 \\
\hline $0.25-0.5 \mathrm{Ha}$ & -0.11 & 0.05 & 0.04 & -0.22 & -0.01 \\
\hline$>0.5 \mathrm{Ha}$ & - & - & - & - & - \\
\hline \multicolumn{6}{|c|}{ Commercial farmer } \\
\hline Yes & 0.15 & 0.05 & 0.01 & 0.04 & 0.25 \\
\hline No & - & - & - & - & - \\
\hline \multicolumn{6}{|c|}{ Member of a cooperativea } \\
\hline Yes & -0.04 & 0.05 & 0.44 & -0.13 & 0.06 \\
\hline No & - & - & - & - & - \\
\hline
\end{tabular}

DADO = District Agriculture Development Office; $\mathrm{Ha}=$ hectare.

a All of the farmer characteristics except cooperative membership were statistically significant in this regression at the $p<0.05$ level. and magnitude of the association between farmer characteristics and government responsiveness. All of the farmer characteristics except cooperative membership were statistically significant in this regression at the $p<0.05$ level. Being a DADOregistered farmer was associated with a 0.19 increase in responsiveness, whereas $\mathrm{iDE}$ farmers were associated with a 0.46 increase in responsiveness. Being located in Gulmi was associated with a 0.25 decrease in responsiveness, and being a female farmer was associated with a 0.12 decrease in responsiveness. Ethnic group differences were also significant, with the lower responsiveness for traditionally less privileged groups. The coefficients for Dalit and Janajati ethnic groups were -0.18 and -0.15 , respectively. Land size was also associated with total responsiveness: farming less than a quarter hectare was associated with a 0.13 decrease in total responsiveness, and farming between 0.25 and 0.5 hectares had a coefficient of -0.11 . Finally, commercial farmers were associated with a 0.15 increase in responsiveness

\section{Discussion}

In this pilot study, we measured the responsiveness of local government to farmers in Nepal. We assessed equity of responsiveness by analyzing how responsiveness varied across several socioeconomic categories, including gender, ethnicity, land size, and commercialization. We also looked at how service responsiveness and equity varied between farmers registered with a DADO, those taking part in iDE programs, and those affiliated with neither. Finally, we tested a direct measure of responsiveness, that is, the percentage of farmers receiving the services they ranked as top priorities to receive.

We found that total agricultural service responsiveness was 59 percent, which means that farmers received 59 percent of the services they ranked as priorities. We also found that service responsiveness varies significantly: farmers across all lower socioeconomic categories (Dalits, Janajatis, women, farmers with less than half a hectare of land, and subsistence farmers) received lower than average responsiveness. These differences were confirmed by multivariate regression, which found statistically 
significant negative coefficients ranging from -0.11 to -0.18 associated with these socioeconomic characteristics. This means that, controlling for other socioeconomic factors, district, and farmer affiliation, farmers in these lower socioeconomic groups can expect to receive between 11 and 18 percentage points lower agricultural service responsiveness. These results suggest inequitable responsiveness to farmer service priorities, though research could test this more robustly by better controlling for confounding structural factors, in particular, distance from roads and towns.

Although our research does not focus on the reasons for this inequitable responsiveness, a few tentative explanations come to mind. One is that participatory service planning may not in fact solicit the views of farmers as well as it is intended to. Our research found that only 3 percent of farmers had knowingly provided input into agricultural planning either directly through meetings with the local government or indirectly through cooperatives or local politicians. This is a problem because service priorities vary significantly by socioeconomic category; consequently, to ensure the inclusion of priorities of these different groups, a larger number of farmers should be consulted. Furthermore, this research does not address the common criticism that even well-targeted services may be vulnerable to elite capture, which affects equity of responsiveness.

Another explanation that does not preclude the previous ones is more structural. Our research provides tentative evidence that those in disadvantaged socioeconomic groups are located in more remote places, making it more expensive for the government to respond to their service priorities. If this is true, it would present service providers with the unenviable choice of increasing service equity or responsiveness. The potential difference in remoteness may also explain why a low percentage of farmers from lower socioeconomic strata are registered with a DADO. These tentative hypotheses could be tested through future research.

We also found significant differences in responsiveness by farmer affiliation. Total responsiveness was highest for iDE farmers, at 85 percent, compared with 54 percent for DADO farmers and 37 percent for farmers affiliated with neither. The significance of these differences was confirmed by regression. The services contributing the most to this responsiveness discrepancy were farmer group development, extension services, and irrigation. These are core components of iDE's program, indicating that at least some of iDE's responsiveness is due to services it provides directly. This suggests that an NGO-led model may have an advantage in responsiveness compared with a DADO, although future research would need to take cost into account to measure efficiency of service delivery.

In measuring responsiveness, we also examined priorities and found that farmers affiliated with neither a DADO nor iDE ranked roads as a priority nearly twice as frequently as DADO and iDE farmers. This lends some support to the hypothesis that farmers in the Neither category were more remotely located. The only significant service priority difference between commercial and non-commercial farmers was roads, which are a higher priority for non-commercial farmers, perhaps indicating that they viewed roads as a key constraint to their commercialization. Another key finding was that although Dalits and Janajatis preferred to receive their technical assistance through traditional extension services, those in the traditionally better educated ethnic groups encompassed by the Other category preferred to receive their technical advice through their input providers. This indicates that scarce extension service resources may be allocated more efficiently by targeting groups such as Dalits and Janajatis.

We also looked at program targeting by socioeconomic characteristics and found significant difference in targeting by gender, ethnic grouping, and land sizes. iDE targeted a higher percentage of women, Dalits and Janajatis, and smallholder farmers than DADOs did. Nevertheless, both DADOs and iDE worked with a lower percentage of Dalits and Janajatis than are in VDCs outside their programs. However, both iDE and DADO farmers were more likely to have less than a hectare of land than were those farmers not in either program. A tentative hypothesis for these seemingly contradictory findings is that these areas are more remote and land values are lower. 


\section{Conclusion}

Nepal's Agricultural Development Strategy prioritizes improved agricultural service coverage and equity of coverage. To achieve this with limited resources, Nepal will have to become more responsive in its provision of agricultural services. That is, it must become better at delivering to farmers the services they prioritize and avoid spending scarce resources delivering to farmers services that are not priorities. By better incorporating farmer input into participatory planning, Nepal can better target services, improving responsiveness to all citizens, including traditionally disadvantaged groups. Furthermore, future research may provide opportunities to efficiently improve services on the basis of socioeconomic and geographic grouping. For example, as the study found, Dalits and Janajatis prefer to receive their technical assistance through extension services, whereas those in the Other ethnic group category prefer embedded services. This is the type of information that could allow service providers to better target services and increase responsiveness within limited resources.
Another way to improve responsiveness is for local governments to collaborate more frequently with NGOs such as iDE. iDE's collaboration with local government results in greater responsiveness and equity as it brings additional resources, along with donor mandates to reach a high percentage of disadvantaged groups and provide specialized expertise. Such collaboration, or at least coordination, if formalized, should be counted both as increased local government responsiveness as well as the NGOs' achieving their donor targets.

Finally, a direct measurement of responsiveness such as the one used here is a straightforward way for governments, donors, and researchers to track and understand changes in responsiveness over time, both across subnational levels and between countries. This direct measurement can in turn improve responsiveness and equity through better targeting on the basis of the service preferences of different socioeconomic and geographic subgroups of service users.

\section{References}

Asian Development Bank (ADB), Department for International Development (DFID), and International Labour Organization (ILO). (2009). Nepal: Critical development constraints. Mandaluyong City, Philippines: ADB. Retrieved February 13, 2013, from http://www.adb.org/ publications/nepal-critical-developmentconstraints

Andersson, K., de Anda, G. G., \& van Laerhoven, F. (2009). Local governments and rural development: Comparing lessons from Brazil, Chile, Mexico and Peru. Tucson, AZ: University of Arizona Press.

Andrews, W., \& van de Walle, S. (2012). New public management and citizens' perceptions of local service efficiency, responsiveness, equity and effectiveness (COCOPS Working Paper No. 7). Retrieved August 4, 2013, from http:// www.cocops.eu/wp-content/uploads/2012/08/ COCOPS_workingpaper_No7-.pdf
Besley, T., \& Burgess, R. The political economy of government responsiveness: Theory and evidence from India. Quarterly Journal of Economics, 117(4), 1415-1451.

Bratton, M. (2010). Citizen perceptions of local government responsiveness in Sub-Saharan Africa (Afrobarometer Working Paper No. 119). Retrieved August 4, 2013, from http://www. afrobarometer.org/publications/working-papers

Central Bureau of Statistics (CBS), Federal Democratic Republic of Nepal. (2011). NEPAL small area estimation of poverty, 2011 (summary and major findings). Appendix tables with small area estimations of poverty on the level of the district, ilaka, target-area and VDC. Retrieved August 5, 2013, from http://cbs.gov.np /wp-content/uploads/2013/06/Small\%20Area $\% 20$ Estimates\%20of\%20Poverty,\%202011.pdf 
Cleary, M. R. (2007). Electoral competition, participation and government responsiveness in Mexico. American Journal of Political Science, 51, 283-299.

Faguet, J. (2004). Does decentralization increase government responsiveness to local needs? Evidence from Bolivia. Journal of Public Economics, 88, 867-893.

Government of Nepal. (1999). Local Self-Governance Act (2055). Retrieved February 11, 2013, from Nepal Law Commission website, http://www. lawcommission.gov.np/en/prevailing-laws /Prevailing-Laws/Statutes---Acts/English /Local-Self-governance-Act-2055-(1999)/

Ministry of Agricultural Development, Nepal (MAD). (2013). Agricultural development strategy. Retrieved August 4, 2013, from http://www.moad. gov.np/ads/index.php?pageid=153

Ministry of Local Development, Nepal (MLD). (2011). Minimum conditions (MCs) and performance measurements (PMs) assessment result of all LBs for the FY 2065-66 and its effects in capital grant allocation for the FY 2067-68. Retrieved February 11, 2013, from Local Governance and Community Development Program (Phase II) website, http:// www.lgcdp.gov.np/home/files/MCPMs\%20 assessment $\% 20$ result $\% 20$ for $\% 20$ the $\% 20 \mathrm{FY} \% 20$ 2066-67.pdf

Oxhorn, P., Tulchin, J.,S., \& Selee, A. (Eds.). (2004). Decentralization, democratic governance, and civil society in comparative perspective: Africa, Asia, and Latin America. Washington, DC: Woodrow Wilson Center Press.

Rodden, J., \& Wibbles, E. (2012, November 26). Responsiveness and accountability in local governance and service delivery: An agenda for USAID program design and evaluation. Retrieved August 4, 2013, from http://people.duke.edu / ew41/Research_files/rodden_wibbels_ nov26_12.pdf

Seth, A. (2009). Institutions and rural services: Lessons from IFAD-supported projects in Asia. International Fund for Agricultural Development (IFAD) occasional papers. Rome, Italy: IFAD. Retrieved February 12, 2013, from http://www.ifad.org /operations/projects/regions/pi/paper/9.pdf
Speer, J. (2012). Participatory governance reform: A good strategy for increasing government responsiveness and improving public services? World Development, 40(12), 2379-2398.

Swanson, B. E., \& Samy, M. M. (2003). Decentralization of agricultural extension systems: Key elements for success. Washington, DC: World Bank. Retrieved February 12, 2013, from http:// info.worldbank.org/etools/docs/library/51025/ ZipAgExtension1/ag_extension1/Materials/ May6Session1/Decentralization-India4-18-03_ paper.pdf

US Agency for International Development (USAID). (2012). Feed the Future: Nepal. Retrieved February 11, 2013, from http://www.feedthefuture.gov/ country/nepal

Wiggins, S., \& Cabral, L. (2007). Politics and the future of ministries of agriculture: Rethinking roles and transforming agendas (Policy Brief 015). Available from Future Agricultures website, http://www. future-agricultures.org/component/docman/doc_ details/144-politics-and-the-future-of-ministriesof-agriculture-rethinking-roles-and-transformingagendas

World Bank. (2012). Global monitoring report 2012: Food prices, nutrition, and the Millennium Development Goals. Washington, DC:

World Bank. Retrieved February 11, 2013, from http://siteresources.worldbank.org/ INTPROSPECTS/Resources/3349341327948020811/8401693-1327957211156 /8402494-1334239337250/Full_Report.pdf

World Bank. (2004). World Development Report 2004: Making services work for poor people. Washington, DC: World Bank. Retrieved August 4, 2013, from http://wdronline.worldbank.org/worldbank/a /c.html/world_development_report_2004/abstract /WB.0-8213-5468-X.abstract 


\section{Acknowledgments}

I am grateful to iDE (International Development Enterprises), Nepal, which generously provided local expertise, contacts, and enumerators to conduct this study. I am also grateful to Charles Lau, PhD, RTI, for his methodological input into this research and Philip Psilos, RTI, for his help developing the initial research idea. 
RTI International is an independent, nonprofit research organization dedicated to improving the human condition by turning knowledge into practice. RTI offers innovative research and technical solutions to governments and businesses worldwide in the areas of health and pharmaceuticals, education and training, surveys and statistics, advanced technology, international development, economic and social policy, energy and the environment, and laboratory and chemistry services.

The RTI Press complements traditional publication outlets by providing another way for RTI researchers to disseminate the knowledge they generate. This PDF document is offered as a public service of RTI International. 